\title{
Youngest Child Having Continuous Ambulatory Peritoneal Dialysis in Bangladesh : A Case Report
}

\author{
A N M Saiful Hasan ${ }^{1 *}$ \\ Anwar Hossain Khan \\ Mohammed Maruf- Ul- Quader ${ }^{2}$ \\ A B M Mahbub UI Alam ${ }^{1}$ \\ Saukat Ara Begum ${ }^{1}$ \\ Sukhamoy Kangsha Banik' \\ Md Delwar Hossain ${ }^{1}$ \\ Rokeya Begum
}

'Department of Pediatric Nephrology National Institute of Kidney Diseases and Urology (NIKDU) Dhaka, Bangladesh.

${ }^{2}$ Department of Pediatric Nephrology Chittagong Medical College Chittagong, Bangladesh.

\begin{abstract}
A 7 months old girl of a non-consanguineous parents admitted in the Department of Pediatric Nephrology, National Institute of Kidney Diseases and Urology (NIKDU), Sher-E-Bangla Nagar, Dhaka, who was diagnosed ultimately as a case of Chronic Kidney Disease (CKD) stage V. She had no family history of renal disease. Initially she was treated with Intermittent Peritoneal Dialysis (IPD). Later she was put on Continuous Ambulatory Peritoneal Dialysis (CAPD). With CAPD her serum creatinine gradually decreased and her general wellbeing becomes stable. She was the youngest child who had CAPD in Bangladesh.
\end{abstract}

Key words: CKD; IPD; ESRD; CAPD.

\section{INTRODUCTION}

Peritoneal dialysis has different methods and one of them is Continuous Ambulatory Peritoneal Dialysis (CAPD) and it has been an popular mode of renal replacement therapy (RRT) in children since $1978^{1}$. Currently CAPD is the predominant mode of RRT in children. In NIKDU children having CKD are advised to do CAPD and to continue it till renal transplantation. During continuous ambulatory peritoneal dialysis (CAPD) fluid remains into the peritoneal cavity for few hours, allowed for diffusion of waste products into CAPD fluid and then drained out. This process is repeated several times a day, can effectively replace kidney function. It is a continuous process without any machine which allows children of CKD stage $\mathrm{V}$ to carry on normal activities. In Bangladesh, the first pediatric CAPD was performed in 2003 at National Institute of Kidney Diseases and Urology (NIKDU) to a 10 years old boy. Since then this center performing CAPD among CKD child patients who are less then 12 years of age.

\section{CASE REPORT}

A 7 months old baby, $2^{\text {nd }}$ issue of non - consanguineous parents, suddenly developed vomiting with loose motion for several times within 24 hours and gradually became lethargic. She vomited for 10 to 12 times and her stool was watery in nature. Her parents at first tried to gave her oral rehydration therapy at home but she took a little and then she was treated under a pediatrician who prescribed her medications. Subsequently she became anuric and unconscious. Her haemoglobin was $8.4 \mathrm{gm} / \mathrm{dl}$ and serum creatinine was $9.5 \mathrm{mg} / \mathrm{dl}$ at that time. So, she was admitted to a hospital and was diagnosed as AKI (Acute Kidney Injury) failure stage. Intermittent peritoneal dialysis (IPD) was done but she improves a little. After three days of completing her IPD she got admitted at our paediatric nephrology department. During admission she had respiratory distress with puffy face, she was conscious but still anuric, hypertensive (BP130/80) $\mathrm{mm}$ of $\mathrm{Hg}$, pulse rate $88 / \mathrm{min}$. Her serum creatinine level was $9.6 \mathrm{mg} / \mathrm{dl}$, serum urea $205 \mathrm{mg} / \mathrm{dl}$, serum electrolytes showed serum sodium $106 \mathrm{mmol} / \mathrm{L}$, serum potassium $5.61 \mathrm{mmol} / \mathrm{L}$, serum chloride 83 $\mathrm{mmol} / \mathrm{L}$ and $\mathrm{TCO}_{2} 12 \mathrm{mmol} / \mathrm{L}$. Hb\% $9.8 \mathrm{gm} / \mathrm{dl}$. Peripheral blood film showed normal study, Urine routine microscopic examination $(\mathrm{R} / \mathrm{M} / \mathrm{E})$ showed albumin ++ , RBC- nil, pus cell- 2-4/ hpf, urinary protein creatinine ratio was 1.56 , Serum cholesterol $98.7 \mathrm{mg} / \mathrm{dl}$. USG of Kidney-Ureter -Bladder (KUB) shows both kidneys are normal in size, shape and position.
Dr. A N M Saiful Hasan Assistant Registrar

Department of Pediatric Nephrology National Institute of Kidney diseases and Urology (NIKDU) Dhaka, Bangladesh.

Mobile: +8801726662484

E-mail: noman162003@yahoo.com 
As her general condition were deteriorating intermittent peritoneal dialysis (IPD) was done and which was continued for about 72 hours with blood transfusion was given. After dialysis her serum creatinine level remains $7.8 \mathrm{mg} / \mathrm{dl}$, serum urea $113 \mathrm{mg} / \mathrm{dl}$, serum electrolytes show sodium $-128 \mathrm{mmol} / \mathrm{L}$, Potassium -4.98 $\mathrm{mmol} / \mathrm{L}$, Chloride $-98 \mathrm{mmol} / \mathrm{L}, \mathrm{TCO}_{2}-15$ $\mathrm{mmol} / \mathrm{L}$. Her consciousness became stable but due to her raised serum creatinine level IPD was done again. After completion of IPD, her serum creatinine remains $7.2 \mathrm{mg} / \mathrm{dl}$ with serum electrolytes was sodium $117 \mathrm{mmol} / \mathrm{L}$, potassium $5.4 \mathrm{mmol} / \mathrm{L}$, chloride $87 \mathrm{mmol} / \mathrm{L}, \mathrm{TCO}-16 \mathrm{mmol} / \mathrm{L}$. It was decided to do CAPD with consultations of her parents and CAPD was done. After CAPD her serum creatinine level gradually decreases as well as gradual improvement of her general condition. Her CAPD cycle continued for 4 times daily-3 exchanges in day and 1 night exchange. During discharge from hospital her blood pressure was $80 / 50 \mathrm{~mm}$ of $\mathrm{Hg}, \mathrm{Hb} \% 11.4 \mathrm{gm} / \mathrm{dl}$, serum urea 40 $\mathrm{mg} / \mathrm{dl}$, serum creatinine was $3.1 \mathrm{mg} / \mathrm{dl}$ with serum electrolytes sodium $138 \mathrm{mmol} / \mathrm{L}$, potassium $-4.1 \mathrm{mmol} / \mathrm{L}$, chloride 98 $\mathrm{mmol} / \mathrm{L} \mathrm{TCO}_{2}-22 \mathrm{mmol} / \mathrm{L}$. Parents were counseled on several sitting and advised to take erythropoietin fortnightly and vaccination properly. After two weeks of discharge from hospital her parents took her to hospital again with severe respiratory distress with slight swelling all over her face. Her blood pressure was $90 / 70 \mathrm{~mm}$ of $\mathrm{Hg}$, pulse rate $88 / \mathrm{min}$. Her serum creatinine level was $3.6 \mathrm{mg} / \mathrm{dl}$, serum urea $80 \mathrm{mg} / \mathrm{dl}$, serum electrolytes showed serum sodium $136 \mathrm{mmol} / \mathrm{L}$, serum potassium $5.01 \mathrm{mmol} / \mathrm{L}$, serum chloride $88 \mathrm{mmol} / \mathrm{L}$ and $\mathrm{TCO}_{2}$ $18 \mathrm{mmol} / \mathrm{L}, \mathrm{Hb} \% 9.5 \mathrm{gm} / \mathrm{dl}$, Urine routine microscopic examination (R/M/E) showed albumin ++, RBC- nil, pus cell$1-3 / \mathrm{hpf}$. On query it was found that her parents were not doing CAPD properly. Sometimes they maintain the CAPD cycle 2 to 3 three times daily as they were frustrated, mentally and physically exhausted. So her CAPD was maintained with $2.25 \%$ CAPD fluid at hospital, 72 hours later of this prescription she improved. We advised to continue CAPD properly and replaced the fluid by $1.25 \%$ CAPD fluid. Within one week she became playful and was released from hospital. Three months after her CAPD she was reasonably well with serum creatinine level $2.1 \mathrm{mg} / \mathrm{dl}$, serum electrolytes within normal limit, $\mathrm{Hb} \%$ was $10.4 \mathrm{mg} / \mathrm{dl}$, she maintained her erythropoietin regularly, Blood pressure became $90 / 70 \mathrm{~mm}$ of Hg USG of KUB showed her both kidneys were smaller in size according to age with increased echogenecity of the cortex and poor cortico-medullary differentiation. She was in CKD stage V. This patient responded well with maintaining CAPD. But after six months when her parents took her to their village on vacation, she developed peritonitis with severe anemia due lack of hygiene, nutrition and inadequate monitoring. So she again admitted in our hospital and we found her febrile, irritable, toxic, loose motion with abdominal tenderness. Her Urine routine microscopic examination $(\mathrm{R} / \mathrm{M} / \mathrm{E})$ showed albumin ++ , RBC- nil, pus cell- 4-6/ hpf, serum creatinine was $3.6 \mathrm{mg} / \mathrm{dl}$, serum electrolytes within normal limit, $\mathrm{Hb} \%--6.4 \mathrm{gm} / \mathrm{dl}$, serum albumin $1.8 \mathrm{mg} / \mathrm{dl}$, total WBC count was $12800 / \mathrm{mm} 3$, culture of peritoneal fluid showed growth of staphylococcus aureus .With the use of appropriate antibiotics according to sensitivity both intravenously and intraperitonially along with blood transfusion her general condition improved. Within a week she became afebrile, abdomen became soft, $\mathrm{Hb} \%$--9.4 gm/dl, serum creatinine was $1.8 \mathrm{mg} / \mathrm{dl}$. We discharged her after improvement of the condition but found her parents giving more attention towards healthy child than this CAPD child.

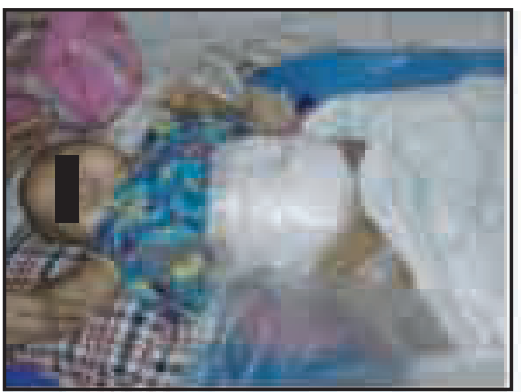

Picture $1: 24$ hours after CAPD catheter placement

\section{DISCUSSION}

Continuous ambulatory peritoneal dialysis therapy in small children is becoming popular day by day but high mortality rate, frequent infections and poor growth are very common in this group of patients ${ }^{2-7}$. CAPD was conceptualized and first used by Popovich and Moncrief in $1976^{8}$. CAPD catheter is surgically placed in the peritoneal cavity. A volume of fluid according to BSA is introduced into the abdomen over ten to fifteen minutes ${ }^{8}$. The volume is referred to as fill volume or $\mathrm{dwel}^{4}$ while the fluid itself is referred to as dialysate. The medication can also be added to the fluid immediately before infusion'. The dwell remains in the abdomen and waste products diffuse across the peritoneum. After a dwell time depending on the PD prescription (usually 4-6 hours/ exchange) the fluid is removed and replaced with fresh fluid'. So fluid is kept in the abdomen for whole day, exchanging the fluids four to six times per day ${ }^{10-11}$. In this patient fluid was exchanged four times a day (three day time exchanges and one night time exchange). The fluid used contains sodium, chloride, bicarbonate and glucose. Glucose as osmotic agent for ultrafiltration. Amount of dialysis that occurs depends on the volume of the dwell, the regularity of the exchange and the concentration of the fluid. CAPD involves four dwells per day with each remaining in the abdomen for 4-6 hours.

This infant having Intermittent peritoneal dialysis for three times before doing CAPD. After CAPD catheter placement dialysis was started with close monitoring of her vital parameters and surgical site. This patient responded well with maintaining CAPD. But after two months of CAPD parents became less attentive toward the diseased child so they did not maintain the cycle properly. So her condition diteriorated. But after councelling, they maintained it properly. Four months later she developed peritonitis due to long travel to her village with her familly associated with lack of hygiene and nutrition. In three studies albumin levels $<3 \mathrm{~g} / \mathrm{dl}$ was associated with an approximately two-fold risk for peritonitis ${ }^{12-14}$. Malnutrition is the most common reason behind it. Culture of peritoneal fluid showed staphylococcus aurious. It has been linked to increased risk of peritonitis ${ }^{15}$. It was obvious that her parents took less attention to her due mental and physical exhaustion. For this infant continuous cyclical peritoneal dialysis (CCPD) was the choice, unfortunately CCPD is not available in Bangladesh till now.

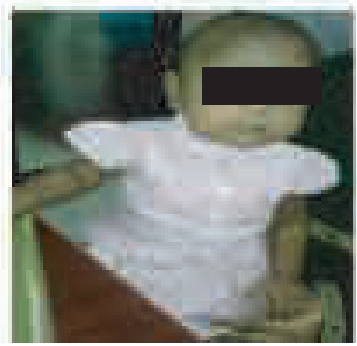

Picture 3 : At 3 months of CAPD 


\section{CONCLUSION}

In 2004 worldwide survey of patients with End Stage Renal Disease (ESRD), approximately $11 \%$ were receiving $\mathrm{CAPD}^{16}$, compared to the much more common hemodialysis. In the United Kingdom, South Korea and Mexico CAPD was more common than the world average, with Mexico conducting most of its dialysis (75\%) through CAPD, while Japan and Germany had rates lower than the world average ${ }^{16}$. In Bangladesh total number of patients receiving CAPD is not known, but in NIKDU at Pediatric Nephrology department we have done 19
CAPD among 248 CKD stage 5 patients who were admitted during the last 9 years ( 2003 -- 2012). She was the youngest CAPD recipient in Bangladesh. We had done this CAPD with great opportunity to establish CAPD among infants in Bangladesh. Although motivation of parents, logistic support like CCPD machine, dedicated rehabilitation program needs more concentration to establish continuous PD to sustain life till transplantation among infant in Bangladesh.

\section{DISCLOSURE}

All the authors declared no competing interest.

\section{REFERENCES}

1. Balfe JW. Continuous Peritoneal Dialysis in Children: Past, Present and Future. Saudi J Kidney Dis Transpl. 1997;8:279-284.

2. Bunchman TE. Chronic dialysis in the infant less than 1 year of age. Pediatr Nephrol. 1999;9:18-23.

3. Bunchman TE. Infant dialysis: the future is now. J Pediatr. 2000;136:1-2.

4. Carey WA, Talley LI, Sehring SA, Jaskula JM, Mathias RS. Outcomes of dialysis initiated during the neonatal period for treatment of end-stage renal disease: A North American Pediatric Renal Trials and Collaborative Studies Special Analysis. Pediatrics. 2007;11:468-473.

5. Rees L. Long-term peritoneal dialysis in infants. Perit Dial Int. 2007;27:180-184.

6. Rees L. Management of the infant with end-stage renal failure. Nephrol Dial Transplant. 2002;17:1564-1567.

7. Wood EG, Hand M, Briscoe DM, et al. North American Pediatric Renal Transplant Cooperative Study (2001) Risk factors for mortality in infants and young children on dialysis. Am J Kidney Dis. 2002;37:573-579.

8. Popovich RP, Moncrief JW, Decherd JF, Bomar JB, Pyle WK. The definition of a novel wearable/ portable equilibrium peritoneal dialysis technique. Trans Am Soc Artif Intern Organs (Abstract). 1976;5:64.

9. Best practices: evidence-based nursing procedures. Lippincott Williams \& Wilkins. 2007. pp. 471-7. ISBN 1-58255-532-X.

10. Crowley, LV. An Introduction to Human Disease: Pathology and Pathophysiology Correlations. Jones \& Bartlett Publishers. 2009;507-509. ISBN 0-7637-6591-0.

11. McPhee, SJ; Tierney LM; Papadakis MA. Current medical diagnosis and treatment. McGraw-Hill. 2007;934-935. ISBN 0-07$147247-9$.

12. Lobo JV, Villar KR, de Andrade Júnior MP, Bastos KA. Predictor factors of peritoneal dialysis-related peritonitis. Jornal Brasileiro de Nefrologia. 2010;32(2):156-164.

13. Prasad N, Gupta A, Sharma RK, Sinha A, Kumar R. Impact of nutritional status on peritonitis in CAPD patients. Peritoneal Dialysis International. 2007;27(1):42-47.

14. Duranay M, Kanbay M, Turgut F, Altay M, Akcay A. Comparison of incidence of peritonitis between peritoneal dialysis solution types. Nephron-Clinical Practice. 2007;106(1):c57-c60.

15. B.piraino, J.A.Permutter, J.L.Holley and J. Bernerdini " staphylococcus peritonitis associated with Staphylococcus aurius nasal carriage in peritoneal dialysis patients" Peritoneal Dialysis International. 13(2):5332-S334.

16. Grassmann, A; Gioberge S; Moeller S; Brown G (2005). "ESRD patients in 2004: global overview of patient numbers, treatment modalities and associated trends". Nephrology Dialysis Transplantation. 2005; 20(12):2587-2593. DOI:10.1093/ndt/gfi159. PMID 16204281. 